\title{
AMHTS における自動現像機の写真性管理について
}

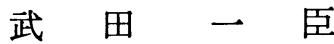

当センターでは, 健診部門が主であるためエックス線 フィルムの現像は, 上部消化管エックス線撮影と胸部エ ックス線撮影の現像処理が，ほとんどを占めている。従 って, ある程度一定した現像処理過程を毎日行なってお り,このことは, 自動現像機の写真性管理がしやすいと 考え，実験及び検討を加えてみた。また，日常のエック ス線写真撮影に対し，常に安定した情報を得られるよう にとの考えから，より簡単で実際的な方法を模索した。

実験方法は，センシトメーター（デュポン社）を用い て， 4 切フィルムの両端に階段露光を与える。これを半 分に切り離し，2台の自動現像機にそれぞれ流して現像 し, 濃度計（フジ Model 301）を用いてグラフに書き, 毎日様子をみた。

まず，2台の自動現像機の特性を揃えることから始め た。これは,どちらの自動現像機に流して現像しても， 恒に安定した, 同じ仕上りの写真を得たいと思ったから である。

現像されたフィルムには, 露光番号がふってあるので 横軸に露光番号, 縦軸に濃度をとりグラフに書くと, き れいな特性曲線を描くことができる。2 台の自動現像機 でそれぞれ現像しているので，2本の特性曲線が重なれ ば，良しとした。

次に 2 台の自動現像機の特性が，このままの状態をず っと維持していけるかどうかを調べてみた。方法は露光 番号を 6 ヶ所抜粋して濃度测定点と定め, 毎日濃度を測 定してグラフに記入した。見た目では全く変化を感じな
いが濃度計で測定すると，わずかな変動を示した。この 変動する濃度幅の許容值を設定するため実験を行なった 結果，自動現象機の現像設定温度を通常の状態から上下 に $1^{\circ} \mathrm{C}$ ずつ変化させたとさの濃度幅が，ちょうどよい 結果となった。以上のことから，2台の自動現像機の写 真性特性を揃え，かつ毎日同じ状態を維持していけるこ とがわかった。

次に適性補充量を調べてみた。今回の実験は，日常の 業務中に行なっているため，読影に支障をきたさないよ う, かぶり濃度の許容值である濃度0.18になった時点で 実験を中止することにした。結果は，最初に流していた 補充量に比べ約 $23 \%$ 節約となった。

最後に，今まで述べてきた方法を応用してェックス線 装置の撮影条件の管理についてのべる。当センターで は, ルーチン撮影が主たる業務であることと，健康な人 が多く受診しており，特殊な撮影がほとんどないためフ ォトタイマーの利用が理想的と言える。週二回, 水ファ ントームを用いて撮影し，その濃度を計ってェックス線 装置の撮影条件の管理としている。極単な濃度のバラッ キが少ないことから，ほぼ満足すべき結果であると考光 ている。以前は，括おざっぱな濃度值だけでやっていた が，現在は 1 台 1 台濃度值を決め，この数值が持続でき るよらにフォトタイマーの調整を行なっている。これも 自動現象の写真管理が充分にできているからであると言 える。

\footnotetext{
A study on photographic control of Automatic

Processor in AMHTS

PL 東京健廉管理センター
} 